\title{
Assessment of Financial Deepening on the Growth of Nigerian Economy: 1990- 2016
}

\author{
Echekoba Felix Nwaolisa \\ Department of Banking and Finance, Faculty of Management Sciences, Nnamdi Azikiwe University Awka, Nigeria \\ Email:nwaolisa@yahoo.com; fn.echekoba@unizik.edu.ng \\ Ubesie Madubuko Cyril \\ Department of Accountancy,Faculty of Management Sciences, Enugu State University of Science and Technology Enugu State, Nigeria \\ Email: ubesiemadubuko@yahoo.com
}

Received: 5 July 2019; Revised: 15 August 2019; Accepted: 2 August 2019; Published: 13 September 2019

\begin{abstract}
This study was on the assessment of financial deepening on the growth of Nigerian -economy 1990ᄀ-2016. The main objective of this study is to evaluate the effect of private sector credit, money supply and market capitalization on economic growth in Nigeria. The sources of data for this study are CBN statistical Bulletin and National Bureau of Statistics. The data obtained were analyzed using ordinary least square regression (OLS). The result of the analyses showed that the three independent variables of the study all have significant effect on Nigerian financial deepening. It was therefore recommended that policy makers should consider reducing impediments to liquidity in the stock market, easing restrictions on international capital and entry into the market to ensure that more companies are listed, policies aimed to reduce the high incidence of non performing credits to ensure that private sector credits are channeled to the real sector of the economy and monetary authorities should implement policies that increase the flow of investible funds and improves the capacity of banks to extend credit to the economy as this will make broad money supply and private sector, to significantly impact on economic growth in Nigeria.
\end{abstract}

Keywords: Financial deepening, Growth

\section{Introduction}

Financial deepening is to improve economic conditions through increased competitive efficiency within financial markets thereby indirectly benefiting non-financial sectors of the economy. Financial deepening also helps in increasing the provision and choices of financial services which would come through its financial infrastructure. Nzotta and Okereke (2009) ascertain that financial deepening is the ability of financial institutions in an economy to effectively mobilize savings for investment purposes. Financial deepening vigorously attracts the reservoir of savings and idle funds and allocates same to entrepreneurs, business, households and government for investments projects and other purposes with a view of returns which forms the basis for economic growth.

The growing importance of stock market and banks around the world has recently opened a new avenue of research into the relationship between financial deepening and economic growth (Arestis, Demetriades and Luintel, 2001). The general idea that economic growth is related to financial deepening was first highlighted by Schumpeter in 1911, (Okoli 2010). The financial deepening role in economic growth has received much attention. However, the focus has been almost entirely on bank based financial deepening measures, while ignoring the possible impact of stock market development. Financial reforms have been a regular feature of the Nigeria financial system. The Central Bank of Nigeria (CBN) has been trying hard to ensure that the financial sector in Nigeria maintain a considerable depth and remain liquid with a view to competing effectively within the global financial market. The reforms have evolved in response to the challenges posed by developments in the system such as systemic crisis, globalization, technological innovation and financial crisis. The reforms often seek to act proactively to strengthen the system, thus, there is need to deepen the financial sector and reposition it for growth and integration into the global financial system in conformity with international best practices. 


\subsection{Statement of the Problem}

Over the past few decades, financial deepening and economic growth has attracted significant attention from finance and development experts and has been debated extensively. This debate can be characterized into two main theoretical propositions: the supply-leading hypothesis (Neusser \& Kugler, 1998) and demandleading hypothesis (Patrick, 1966). Supply leading hypothesis suggest that financial deepening spurs growth. The hypothesis contends that the development of financial market can create and expand liquidity, mobilize savings and promote the growth of an economy. The demand following hypothesis financial deepening is merely an outcome of growth in the real sector of the economy which could be allocated to more useful purposes in the early stages of growth. (Odiambho, 2004). Financial deepening plays an important role in determining the growth of an economy. It broadens its resource base, raises the capital needed to stimulate investment through savings and credit, and boost the overall productivity. The design and implementation of effective interventions and programs in the Nigeria banking sector and stock market has led to a continued growth in financial assets, with a direct contribution from financial intermediaries. However, economic growth in Nigeria, whether as a result of financial deepening or other growth factors has been fluctuating over the last decade with rate as low as 0.5 in 1999. Therefore, it is of importance to assess the banking sector and stock market deepening effects on economic growth in Nigeria. The Nigeria economy is one of the largest in Africa, but empirical research have given little emphasis on the nature of financial deepening and economic growth bearing in mind the recent downturn in the financial market and how it affects the real sector of the economy and this have generated a lot of controversies and further research needs to be carried out on the nature of the relationship between the financial sector and economic growth.

\subsection{Objectives of the Study}

The main objective of this study is to examine the effect of financial deepening on economic growth using time series data set in Nigeria from 1990 to 2016. Specifically the study seeks to:

1. Determine the effect of private sector credit on economic growth in Nigeria.

2. Assess the effect of market capitalization on economic growth in Nigeria.

3. Examine the effect of money supply on economic growth in Nigeria.

\section{Research Questions}

This study titled assessment of financial deepening on the growth of Nigerian Economy will be guided by the following research questions:

1. How does private sector credit influence economic growth in Nigeria?

2. To what extent has market capitalization influenced economic growth in Nigeria?

3. To what extent is the effect of money supply on economic growth in Nigeria?

\subsection{Hypotheses of the Study}

The hypotheses therefore are postulated as follows:

1. Ho - Private sector credit has no significant effect on economic growth in Nigeria.

2. Ho - Market capitalization has no significant effect on economic growth in Nigeria.

3. Ho - Money supply has no significant effect on economic growth in Nigeria.

\section{Scope of the Study}

This research work examined financial deepening and economic growth from 1990 to 2016 . The period covered by this study (1990 to 2016) is the grey, boom and doom periods of capital market development in Nigeria. Within this period great stripes were made in the infrastructures, institutions and regulations that pertain to the Nigerian Capital market. This study is not a comparison of the Nigeria financial sector economic deepening with those of other countries. This is based on the fact that focusing on a single country; it will be possible to keep substantial variability within the sample.

\section{Conceptual Review}

\subsection{The Concept of Financial Deepening}

The World Bank (1989) defines it as an increase in the stock of asset. Contributing, Shaw (1973) sees it as a process involving specialization in financial functions and institutions through which organized domestic institution and markets relate to foreign markets. He stressed that an increase in the real size of the monetary 
system will generate opportunity for the profitable operation of other institutions as well via bill dealers to industrial banks and insurance companies. Opinionating, Nnanna and Dogo (1998) said that financial deepening often refers to a state of an atomized financial system, meaning a financial system that is largely free from financial repression. Financial deepening thus is the outcome of accepting appropriate real finance policy such as relating real rate of return to real stock of finance.

Financial deepening generally entails an increased ratio of money supply to Gross Domestic product (Nnanna and Dogo,1998; Nzotta, 2004). Financial deepening is thus measured by relating monetary and financial aggregates such as M1, M2 and M3 to the Gross Domestic Product (GDP).Thus, the definition of financial deepening in literature reflects the share of money supply in GDP. The most classic and practical indicator related to financial deepening is the ratio of $\mathrm{M} 2 / \mathrm{GDP}$ which means the share or M I + all timerelated deposits and non-institutional money market funds to GDP in a certain year. M1, M2, M3 are all measures or money supply, that is the amount of money in circulation at a given time. The logic here is that the more liquid money is available to an economy, the more opportunities exist for continue growth of the economy. How does this come about? Deep and mature financial markets are indispensable for economic development. (Olofin and Afangideh 2010).

The level of financial deepening reflects the soundness of the financial sector and the ability with which credits are created with respect to lending and deposit rates. Financial deepening theory thus defines the positive role of the financial system on economic growth by the size of the sector's activity. That means that an economy with more intermediary activity is assumed to be doing more to generate efficient allocations. In development studies, financial deepening is very often refers to the increased provision of financial services with a wider choice of services geared to the development of all levels of society. The size of the financial sector is usually measured by two basic quantitative indicators: "monetization ratio" and "intermediation ratio". Whereas monetization ratio includes money-based indicators or liquid liabilities like broad money supply to GDP ratio, intermediation ratio consists of indicators concerning to bank-based measures like bank credit to the private sector and capital market-based measures such as capitalization ratio of stock market (Ndebbio, 2004). The financial system comprises various institutions, instruments and regulators. It refers to the set of rules and regulations and the aggregation of financial arrangements, institutions, agents that interact with each other and the rest of the world to foster economic growth and development of a nation (CBN, 1993).

According to Ndebbio (2004), economic growth and development of a country depends greatly on the role of financial deepening. He argued what is important is what constitutes the financial assets that wealthholders must have as a result of high per capita income. It is only when we can identify those financial assets can we be able to approximate financial deepening adequately. In short, and for our purpose, financial deepening simply means an increase in the supply of financial assets in the economy.

Therefore, the sum of all the measures of financial assets gives us the approximate size of financial deepening. That means that the widest range of such assets as broad money, liabilities of non-bank financial intermediaries, treasury bills, value of shares in the stock market, money market funds, etc., will have to be included in the measure of financial deepening (Ndebbio, 2004). To simply pick the ratio of broad money (M2) to gross domestic product (Y), as done in this study, is because of lack of reliable data on other measures of financial assets likely to adequately approximate financial deepening in most SSA countries including Nigeria.

It is important to note that if the increase in the supply of financial assets is small, it means that financial deepening in the economy is most likely to be shallow; but if the ratio is big, it means that financial deepening is likely to be high.

\subsection{The Concept of Economic Growth}

Economic growth is an increase in the capacity of an economy to produce goods and services, compared from one period of time to another. It goes further to explain that economic growth can be measured in nominal or real terms, the latter of which is adjusted for inflation.

Wikipedia explained economic growth as the increase in the inflation-adjusted market value of the goods and services produced by an economy over time. It is conventionally measured as the percent rate of increase in real gross domestic product, or real GDP, usually in per capita terms. It explained that growth is usually calculated in real terms - i.e., inflation-adjusted terms - to eliminate the distorting effect of inflation on the price of goods produced. 
Dugger (2016) said that the "rate of economic growth" refers to the geometric annual rate of growth in GDP between the first and the last year over a period of time. Implicitly, this growth rate is the trend in the average level of GDP over the period, which implicitly ignores the fluctuations in the GDP around this trend.

\section{Theoretical Review}

\subsection{Supply - Leading Theory}

The supply-leading theory suggests that financial deepening spurs growth. The existence and development of the financial markets brings about a higher level of saving and investment and enhance the efficiency of capital accumulation. This hypothesis contends that well-functioning financial institutions can promote overall economic efficiency, create and expand liquidity, mobilize savings, enhance capital accumulation, transfer resources from traditional (non-growth) sectors to the more modem growth inducing sectors, and also promote a competent entrepreneur response in these modern sectors of the economy. The recent work of Dernirguc-Kunt \& Levine (2008) in a theoretical review of the various analytical methods used in finance literature, found strong evidence that financial development is important for growth. To them, it is crucial to motivate policymakers to prioritize financial sector policies and devote attention to policy determinants of financial development as a mechanism for promoting growth.

\subsection{Demand - Following Theory}

The demand-following view of the development of the financial markets is merely a lagged response to economic growth (growth generates demand for financial products). This implies that any early efforts to develop financial markets might lead to a waste of resources which could be allocated to more useful purposes in the early stages of growth. As the economy advances, this triggers an increased demand for more financial services and thus leads to greater financial development.

Some research work postulate that economic growth is a causal factor for financial development.

According to them, as the real sector grows, the increasing demand for financial services stimulates the financial sector. It is argued that financial deepening is merely a by-product or an outcome of growth in the real side of the economy, a contention recently revived by Ireland (1994) and Demetriades and Hussein (1996). According to this alternative view, any evolution in financial markets is simply a passive response to a growing economy.

\subsection{Importance of Financial Deepening}

According to Jalilian and Kirkpatrick (2005) there are some clear links of financial deepening with economic growth in developing countries. Empirical analysis confirms the common finding of a positive relationship between financial deepening and growth, noticeably for poorer developing countries. Finance as a well established supply leading character i.e. the level of financial deepening and stock market liquidity each exerts an independent, positive influence on economy growth. Financial services and financial deepening (as measure by the size of the intermediary sector) stimulates economic growth by increasing the rate of capital accumulation and by improving the efficiency with which economies use that capital in the current period as well as in the future.

Financial deepening can also lead to greater efficiency of financial intermediation (e.g. via intermediation of greater amounts of domestic savings and investment cycles) and thereby greater stability. The diversified funding base of financial institutions has played a role in cushioning the impact of a global credit (wholesale funding) crunch on domestic financial intermediation. (Sahoo, 2013)

\subsection{Financial Deepening and Economic Growth}

Economic growth means the growth in a nation's real gross domestic product (an increase in a nation's output of goods and services) or the physical expansion of the nation's economy. (Antwi, Mills and Zhao, 2013). Economic growth can be illustrated as an upbeat change on the output of a nation's manufacturing goods and services, stretching over a certain period of time (Kanu \& Ozurumba, 2013).

In the view of Ndebbio (2004), financial deepening means an increase in the supply of financial assets in the economy. Therefore, the sum of all the measures of financial assets gives us the approximate size of financial deepening. That means that the widest range of such assets as broad money, value of shares in the stock market, money market funds, etc, will have to be included in the measure of financial deepening. In his study, Ndebbio (2004) note that if the increase in the supply of financial assets is small, it means that financial 
deepening in the economy is most likely to be shallow, but if the ratio is big it means that financial deepening is likely to be high. He further went on to stressed that developed economies are characterized by high financial deepening, meaning that the financial sector in such countries has had significant growth and improvement, which has, in turn, led to the growth and development of the entire economy. Furthermore, He suggested that the financial sector is the conduit through which financial deepening is manifested.

According to Fisher (2001), financial deepening refers to the greater financial resource mobilization in the formal financial sector and the ease in liquidity constraints of banks and enlargement of funds available to finance projects.

The Department for International Development -DFID (2004) defined the financial sector of an economy as the wholesale, retail, formal and informal institutions in an economy offering financial services to consumers, businesses and other financial institutions. It therefore broadly includes everything from banks, stock exchanges, insurers, credit unions, microfinance institutions and money lenders. DFID (2004) further outlined the ways in which the financial sector can be adjudged to be developed or to have deepened and these include improvement in the efficiency and competitiveness of the sector, the range of financial services that are available may increase, the extent to which capital is allocated by private sector financial institutions to private sector enterprises responding to market signals (rather than government directed lending by state owned banks) may increase, the regulation and stability of the financial sector may improve and more of the population may gain access to financial services.

The financial institution has the potential to boost savings and channel it to deficit sector of the economy through extension of credit. This requires a high degree of financial intermediation in the financial sector. Such a come together of the deficit and surplus spending units is likely to result in more deepening of the financial system. (Ghani,2002).

\subsection{Empirical Studies}

Adu, Marbuah and Mensah (2013) investigate the long run effect, financial deepening has on the Ghana economy, using a time series data for 14 years period 1998 to 2011 . Their study used private sector credit ratio to GDP, money supply ratio to GDP, total domestic credit ratio, total bank liabilities ratio and a set of control variables such as trade openness, inflation rate and real gross government expenditure. The study, although useful in the use of more than one measure of financial deepening and the use of control variables, the number of observation of their data points is insufficient to obtain a statistically significant result for the individual variables. The researcher failed to apprehend the fact that the time span of the study draws into question the validity of the finding, as they could be spurious. Econometric theories suggest a minimum 15 year's time series data as a measure of avoiding spurious result in a study.

Agu and Chukwu (2008) studied financial deepening and economic growth in Nigeria from the period of 1970 to 2005. The study used only bank based financial deepening proxies. Financial deepening means an increase in asset and providing level of financial services to the economy. The total amount of financial assets will constitute an optimal measure of financial deepening.

Shittu (2012) examines the impact of financial intermediation on economic growth in Nigeria with time series data from 1970 to 2010. Employing co integration test and error correction model, he finds that financial intermediation has a significant impact on economic growth in Nigeria.

Sulaiman and Azzez (2012) critically explore the effect of financial liberalization on the economic growth in developing nations with its assessment focusing on Nigeria with annual time series data from $1987-2009$. The study employs co-integration and error correction model (ECM) by making Gross Domestic Product as a function of lending rate, exchange rate, inflation rate, financial deepening (M2/GDP) and degree of openness as its financial liberalization indices. Co-integration result confirms the existence of long run equilibrium relationship while the ECM results show a very high R2 in both the over-parameterized model (95\%) and parsimonious model (91\%). The study therefore concludes that financial liberalization has a growthstimulating effect on Nigeria.

Onwumere, Ibe, Ozoh and Mounanu (2012) examines the impact of financial deepening on economic growth in Nigeria for the period of 1992 - 2008 and adopted the supply-leading hypothesis using variables such as broad money velocity, money stock diversification, economic volatility, market capitalization and market liquidity as proxies for financial deepening and gross domestic product growth rate for economic growth. They found that broad money velocity and market liquidity promote economic growth in Nigeria while money stock diversification, economic volatility and market capitalization did not within the period studied. The study recommended that government policy should be geared towards increasing money supply 
and promoting efficient capital market that will enhance overall economic efficiency, create and expand liquidity, mobilize savings, enhance capital accumulation, transfer resources from traditional sectors to growth inducing sectors.

Nwanna \& Chinwudu (2016) examined the effect of financial deepening on economic growth in Nigeria from 1985 to 2014 . They aimed at revealing the impact of stock market and bank deepening variables such as money supply, market capitalization, private sector credit and financial savings have on economic growth of Nigeria. The ordinary least square (OLS) econometric technique was adopted. The result of the analysis reveals that both bank based and stock market financial deepening proxies has significant and positive effect on economic growth and that the banking sector and stock market in Nigeria has an important role in the process of economic growth.

\section{Research Method}

A number of statistical techniques of analysis have been applied by researchers in a bid to assess financial deepening and the growth of Nigerian economy. This research adopted ex-post facto research design to examine this effect on the Nigerian economy over a twenty six years period (1990 -2016). This is to ensure that existing data are enough in the analysis in order to cater for the loss of degree of freedom.

The study employs annual time series data covering the period stated above. This period is chosen as it corresponds to the period where Nigeria financial sector was liberalized and consistent data on the relevant variables are available. More importantly, this period witnessed tremendous reformed to enhance diversification of Nigerian. Data for the study was obtained from Central Bank of Nigeria (CBN) statistical Bulletin and CBN Annual Report and Statement of Accounts various issues.

\subsection{Model Specification}

A model is simply an abstraction of reality. The ordinary least square (OLS) regression is the estimation technique employed in this study. The choice of ordinary least square method was due to its simplicity. The researcher however adopted a model by Ohwofasa and Aiyedogbon (2013), which was modified by the researcher to suit the present research. The model is as specified below:

$\mathrm{GDPGR}_{\mathrm{t}}=\alpha_{\mathrm{o}}+\alpha_{1} \mathrm{CPS}_{\mathrm{t}}+\alpha_{2} \mathrm{MCR}_{\mathrm{t}}+\alpha_{3} \mathrm{M} 2_{\mathrm{t}}+\mathrm{U}_{\mathrm{t}}$

where: GDPGR $=$ Gross Domestic Product Growth Rate

CPS $=$ Ratio of private sector credit to GDP

MCR $=$ Ratio of Market Capitalization to GDP

$\mathrm{M} 2=$ Ratio of money supply to GDP ,u = Error term

\subsection{Model Justification}

The procedure for this estimation adopted for this study is the classical linear regression model using OLS as an estimator. The method of ordinary least square is attributable to Carl Freidrich Gauss, a german mathematician.

This model is the most preferred because it is easy to understand, simple in its computational procedure and parameter estimation. It also possesses the properties of best linear unbiased estimator (BLUE).

\subsection{Economic Apriori Expectation}

This refers to the supposed relationship between one and or among the dependent or independent variables of the model as determined by the postulation of economic theory. The result or the parameter estimate of the models will be interpreted on the bases of the supposed signs of the parameters as established by economic theory. Put differently, the parameter estimate of the model will be checked to find out whether they conform to the postulations of economic theory.

Table 1.

Summary of apriori expectation

\begin{tabular}{|c|c|c|}
\hline Regressand & Regressor & Relationship \\
\hline GDPGR & MCR & + \\
\hline GDPGR & CPS & + \\
\hline GDPGR & M2 & + \\
\hline
\end{tabular}


If the magnitude and signs of the parameter estimates do not conform to economic theory, they should be rejected unless there is a good reason to believe in that particular instance, economic theory does not hold.

\subsection{Estimation Technique and Procedure}

The estimation procedure adopted in this study is in three sequences. To stem the problem of spurious regression, it is important that the time series properties of the data set employed in estimation of equation is ascertained. It might seem reasonable to test for the presence of a unit root in the series using the most general of the models as.

$\Delta y t=\alpha o+Y y t i+\alpha 2 t+\Sigma \beta j \Delta y t-I+$ et

Where $y$ is the series $\mathrm{t}$ is (trend factor); $\alpha \mathrm{O}$ is the constant term, et is the stochastic error term, $\beta$ is the lag length. The Augmented DickeyFuller (ADF) unit root test is employed to test the integration level in order to determine the order of integration of the variables.

\subsection{Unit Root Test}

The use of analytical data in econometric analyses poses several challenges to researchers. Stationarity of the time series data is one of these problems since a time series that is non-stationary is bound to yield spurius regression. A series is said to be stationary if it mean and variance are constant over time and the value of covariance between two time periods and not on the actual time at which one covariance is computed (Gujarati, 1995). Considering that most time series data are non-stationary and therefore produce spurious results, unit root tests should be conducted before testing for co-integration.

The ADF test pertinent to ensure that the modeled variable series posses constant mean and variance. The motivation for such verification is to hedge against spurious regression that may result from applying OLS to variables at their level form when such variables are non-stationary. Also, the ADF test addresses a short coming of the Dickey Fuller test of not considering the possibility of autocorrelation in the error term by adding a lagged difference term and therefore corrects for high-order serial correlation

\subsection{Evaluation of Estimates}

This consists of deciding whether the parameter estimates of the economic relationship or model are theoretically meaningful or satisfactory. Koutsoyinnis (2003) opined that the estimates or results are obtained from the estimation of an econometric model are evaluated on basically three criteria which include the apriori criteria, statistical criteria; first order test, and the econometric criteria second order test.

The economic apriori criteria is as stated in the 3.3.2 economic apriori expectation of this study.

\subsection{The Statistical Criteria: First Order Tests}

This aims at the evaluation of the statistical reliability of the estimated parameters of the model. In this case, F-statistics, T-statistics, co-efficient of determination (R2) and Adjusted R2) as well as the standard error (SE) are used.

The coefficient of Determination (R2) Adjusted R2

The square of the coefficient of determination $\mathrm{R}^{2}$ or the measure of goodness of fit is used to judge the explanatory power of the explanatory variable on the dependent variables. The $\mathrm{R}^{2}$ denotes the percentage of variations in the dependent variable accounted for by the variables in the independent variables. Thus, the higher the $\mathrm{R}^{2}$, the more the model is able to explain the changes in the dependent variable explained by the explanatory variables.

However, if $\mathrm{R}^{2}$ equals one, then it implies that there is $100 \%$ explanation of the variation in the dependent variable by the independent variable and this indicates a perfect fit of regression line. While where $\mathrm{R}^{2}$ equals zero, it indicates that the explanatory variables could not explain any of the changes in the dependent variable. Therefore, the higher and closer the $\mathrm{R}^{2}$ is to 1 , the better the model fits the data. Note, the above explanation goes for the adjusted $\mathrm{R}^{2}$.

The F-test.

The F-statistics is used to test whether or not, there is a significant impact between the dependent variable and the independent variables. In the regression equation, If calculated $\mathrm{F}$ is greater than the table $\mathrm{F}$ value, then there is a significant impact between the dependent and the independent variables in the regression equation. While if the calculated $\mathrm{F}$ is smaller or less than the table $\mathrm{F}$, there is no significant impact between the dependent and the independent variables. 
T-Test.

This is used to determine the reliability or statistical significance of each variable coefficient. Here, the absolute t-value of each coefficient is compared with 1.96 and if greater than 1.96, such variable possessing the coefficient is accepted as statistically significant and fit to be used for inferences and possibly for forcasting.

\subsection{Econometric Criteria: Second Order Test.}

This aims at investigating whether the assumption of econometric method employed are satisfied or not in any particular case. They determine the reliability of any statistical criteria and also establish whether the estimates have desirable properties of unbiasedness and inconsistency. It also tests validity of non- auto correlation disturbances; here, the Durbin-Watson (D-W)is used for the test.

Test for auto-Correlation (DW)

Durbin -Watson is appropriate for the test of first order autocorrelation and it has the following criteria.

(a) If $\mathrm{d}^{*}$ is approximately equal $2\left(\mathrm{~d}^{*}=2\right)$ we accept that there is no auto correlation in the function.

(b) If $\mathrm{d}^{*}=0$, there exist perfect positive auto-correlation. Furthermore, if $\mathrm{O}<\mathrm{d}^{*}<2$, that is if $\mathrm{d}^{*}$ is less than 2 but greater than zero. It denotes that there is some degree of positive autocorrelation which is stronger, the closer $\mathrm{d}^{*}$ is to zero.

(c) If $d^{*}$ is equal to $4\left(d^{*}=4\right)$, there exist a perfect negative auto-correlation while if $d^{*}$ is less than four but greater than $2\left(2<\mathrm{d}^{*}<4\right)$, It means that there exist some degree of negative auto correlation, which is stronger the higher the value of $\mathrm{d}^{*}$.

\section{Test of Research Hypotheses}

T-test is applied to test the statistical significance of the individual parameters in hypothesis. The two tailed test at $5 \%$ significance level is usually conducted in testing the hypothesis.

Decision rule: Reject $\mathrm{H}_{0}$ if $\mathrm{F}_{\text {cal }}>\mathrm{F}_{\alpha}(\mathrm{K}-1, \mathrm{n}-\mathrm{K})$ at $\alpha=5 \%$, accept if otherwise.

Where

$\mathrm{V}_{1} / \mathrm{V}_{2}$ Degree of freedom (d.f)

Where; $n$ (number of observation); $k$ (number of parameters)

However, for regression analyses, the computed regression result is compared with the 0.05 level of significance. Where the regression result, i.e. the probability ( $\mathrm{sig}$ ) is greater than 0.05 ( $\operatorname{sig} \geq 0.05$ ) we accept the null hypothesis, if not, we reject the null hypothesis and accept the alternative, or if the probability (sig) is lesser than $0.05(\mathrm{sig} \leq 0.05)$ accept the alternative hypothesis.

\subsection{Nature and Sources of Data}

The study employs annual time series data covering the period 2007-2017. Data for the study was obtained from CBN Statistical Bulletins

\section{Data Presentation, Analyses and Discussion on Findings}

Following the Johansen co integration framework as described in the previous chapter, the researcher verified the possibility of long run relationships between the dependent variable and the independent variables in the model. We first present the result of the stationarity test using the augmented dickey fuller (ADF) unit root test. This is necessary condition for the Johanson co integration analysis requires that variables be nonstationary in their level forms.

Secondly, after the stationary test, the cointegration analysis using Johanson cointegration analysis comes next. This provides for the model to be subjected to the ordinary least square (OLS) which is used to provide coefficients for the determinants in our model.

\subsection{Summary of Stationary Test}

Establishing stationary is essential because if there is no stationary, the processing of the data may produce biased result. The consequences are unreliable interpretation and conclusions. In executing the tests captured in the table below, it is assumed that the series of the various variables possess an intercept but no trend. It is worthy to mention here that ADF test is run against the null hypotheses that there is nonstationary of the series. And as a rule, once the ADF statistic is greater than the critical value at any chosen level of significance, we reject the null hypothesis and that implies that the data series are stationary. 
Table 2.

Summary of Stationary Test.

\begin{tabular}{|l|c|c|c|c|c|c|}
\hline Variable & $\begin{array}{c}\text { ADF } \\
\text { Statistics }\end{array}$ & $\begin{array}{c}\text { Level } \\
\text { of sig }\end{array}$ & $\begin{array}{c}\text { Lagged } \\
\text { difference }\end{array}$ & $\begin{array}{c}\text { Critical } \\
\text { value }\end{array}$ & Order of integration & Assumption \\
\hline GDPGR & -4.6908 & $5 \%$ & 1 & -3.040 & $1(1)$ & Intercept \\
\hline CPS & -0.9620 & $5 \%$ & 1 & -2.968 & $1(1)$ & Intercept \\
\hline MCR & -3.4573 & $5 \%$ & 1 & -2.912 & $1(1)$ & Intercept \\
\hline M2 & -2.3674 & $5 \%$ & 1 & -2.943 & $1(1)$ & Intercept \\
\hline
\end{tabular}

From the table above, it can be observed that none of the variables are stationary at level difference that is $1(0)$, rather, all the variables are stationary at first difference, that is 1(1). Since the decision rule is to reject rejectstationarity if ADF statistics is less than $5 \%$ critical value, and accept stationarity when ADF statistics is greater than $5 \%$ critical value. The ADF statistics value of each of these variables is greater than $5 \%$ critical value at the first difference. Therefore, they are all stationary at their first difference integration.

\subsection{Johanson Co-Integration Test (Eigenvalue Test)}

Appendix nine shows the co-integration result this work. The statistics test indicates the existence of three co-integrating equations at $5 \%$ significance level in the model. This finding is evidence that there are ample long run relationships amongst the variables in the model. It also validates the conformity of this analysis to the theoretical postulation of long run relationship among economic variables.

Table 3.

Summary of Johansen Co-integration Test

\begin{tabular}{|c|c|c|c|c|}
\hline Variable & Eigenvalue & Trace statistics & $\mathbf{5 \%}$ Critical Value & Hypothesis no of CE(s) \\
\hline GDPGR & 0.888758 & 71.10041 & 27.58434 & At most 1 \\
\hline CPS & 0.538451 & 22.78728 & 21.13162 & At most 2 \\
\hline MCR & 0.347032 & 13.83304 & 17.53742 & At most 1 \\
\hline M2 & 0.483255 & 20.84765 & 19.01463 & At most 1 \\
\hline
\end{tabular}

\subsection{Evaluation of Findings}

For the purpose of discussing the result as obtained in table 4.2 above, we employ economic a priori criteria, statistical criteria and econometric criteria.

\subsection{Evaluation Based on Economic Criteria}

Table 4.

An overview of apriori expectation.

\begin{tabular}{|l|l|l|}
\hline Variables & Expected signs & Remark \\
\hline GDPGR & This is the dependent variable & Dependent \\
\hline CPS & This is expected to be positive $(+)$ & Conform \\
\hline MCR & This is expected to be negative $(+)$ & Conform \\
\hline M2 & This is expected to be negative $(+)$ & Conform \\
\hline
\end{tabular}

\subsection{Evaluation Based on Statistical Criteria}

Statistical evaluation is usually carried out using the $\mathrm{R}^{2}$, The adjusted $\mathrm{R}^{2}$ and the F-test. This is usually carried out to determine the reliability of the estimated parameters.

\subsection{The Coefficient of Determination (R2)}

Coefficient of determination $\left(\mathrm{R}^{2}\right)$ or the measure of goodness of fit is used to judge the explanatory power of the explanatory variable on the dependent variables. The $\mathrm{R}^{2}$ denotes the percentage of variations in the dependent variable accounted for by the variables in the independent variables. Thus, the higher the $\mathrm{R}^{2}$, the more the model is able to explain the changes in the dependent variable explained by the explanatory variables. 
From the result of the analysis in appendix three, the coefficient of determination $\mathrm{R}^{2}$ is given as 0.8523 . This shows that the explanatory power of the variable is extremely high. This shows that $85 \%$ of the variations in the GDP growth rate are being explained by financial deepening indicators.

If $\mathrm{R}^{2}$ equals one, then it implies that there is $100 \%$ explanation of the variation in the dependent variable by the independent variable and this indicates a perfect fit of regression line. While where $\mathrm{R}^{2}$ equals zero, it indicates that the explanatory variables could not explain any of the changes in the dependent variable. Therefore, the higher and closer the $\mathrm{R}^{2}$ is to 1 , the better the model fits the data.

Adjusted $\mathbf{R}^{2}$ : It supports the claim of the $\mathrm{R}^{2}$ with a value of 0.7129 indicating that $71 \%$ of the total variation in the dependent variable is explained by the independent variables. Thus, this supports the statement that the explanatory power of the variables is high and strong.

\subsection{Test of Hypotheses}

Here, the researcher tests the hypotheses using the result obtained from the regression analysis.

\subsection{Decision Rule}

The hypotheses were tested at 0.05 level of significance from regression results, the hypotheses were tested in order to decide whether to accept the alternative hypothesis or accept the null hypothesis. If prob $(\operatorname{sig})>0.05$, we accept the null hypothesis and if prob $(\mathrm{sig})<0.05$, we accept the alternative hypothesis.

\subsection{Hypothesis One}

Ho - Private sector credit has no significant effect on economic growth in Nigeria.

Table 5.

Showing Regression result of relationship between GDP growth rate and the ratio of private sector credit to GDP.

\begin{tabular}{|c|c|c|c|c|c|c|}
\hline \multicolumn{2}{|c|}{ Model } & Sum of Squares & Df & Mean Square & $\mathbf{F}$ & Sig. \\
\hline \multirow{3}{*}{1} & Regression & 18294991090.139 & 1 & 18294991090.139 & 54.501 & $.004^{b}$ \\
\hline & Residual & 4363876454.261 & 25 & 335682804.174 & & \\
\hline & Total & 22658867544.400 & 27 & & & \\
\hline
\end{tabular}

Based on the decision rule stated above, since result of the regression result showed a prob. (sig) value of 0.004 from table 4.4, which is far less than 0.05; we therefore reject the null hypothesis.

Therefore, we conclude that there is significant effect of private sector credit on the growth of Nigerian economy.

\subsection{Hypothesis Two}

Ho: Ho - Market capitalization has no significant effect on economic growth in Nigeria.

Table 6.

Showing Regression result of GDP growth rate and ratio of market capitalization to GDP

\begin{tabular}{|c|c|c|c|c|c|c|}
\hline \multicolumn{2}{|c|}{ Model } & Sum of Squares & Df & Mean Square & F & Sig. \\
\hline \multirow{3}{*}{1} & Regression & 4539252755.916 & 1 & 4539252755.916 & 3.257 & $.016^{\mathrm{b}}$ \\
\cline { 2 - 9 } & Residual & 18119614788.484 & 25 & 1393816522.191 & & \\
\cline { 2 - 9 } & Total & 22658867544.400 & 27 & & &
\end{tabular}

a. Dependent Variable: GDPGR

b. Predictors: (Constant), MCR

Based on the decision rule stated above, since result of the regression result showed a prob. (sig) value of 0.016 from table 4.5, which is less than 0.05; we therefore reject the null hypothesis.

Therefore, we conclude that Market capitalization has significant effect on economic growth in Nigeria for the periods under investigation.

\subsection{Hypothesis Three}

Ho - Money supply has no significant effect on economic growth in Nigeria. 
Table 7.

Showing Regression result of relationship between GDP growth rate and the ratio of broad money to GDP.

\begin{tabular}{|l|l|l|l|l|l|l|}
\hline Model & Sum of Squares & Df & Mean Square & F & Sig. \\
\hline \multirow{4}{*}{1} & Regression & 19194991090.402 & 1 & 25194991090.431 & 51.552 & $.009^{\mathrm{b}}$ \\
\cline { 2 - 8 } & Residual & 4363876454.261 & 25 & 215682804.023 & & \\
\cline { 2 - 8 } & Total & 22558867544.321 & 26 & & & \\
\hline
\end{tabular}

b. Predictors: (Constant), M2

Based on the decision rule stated above, since result of the regression result showed a prob. (sig) value of 0.009 from table 4.6, which is greater than 0.05; we therefore reject the null hypothesis.

Therefore, we conclude that money supply has significant effect on economic growth in Nigeria for the periods under investigation.

\section{Discussion of Findings}

The growth in the market manifested in the phenomenal increase in market capitalization from 4.9 percent in 1990 to 63.81 percent in 2007 . It can be observed from Table 6 that the money supply ratio rose from 11.2 percent in 1990 to 36.7 percent in 2009 and decreased to 19.7 percent in 2014 . The economy witnessed high growth rates in gross domestic product of 33.7 percent in 2004 before it decline to 3.4 percent in 2005 followed by a gradual recovery to 6.3 percent in 2014. A key factor responsible for the results obtained above is these fluctuations in the GDP growth rate and the variations in money supply.

\section{Summary of Findings}

This study on the assessment of the effect of financial deepening on the growth of Nigerian economy from 1990-2016. Following a detailed time series analysis the findings revealed a plausible result on economic growth in Nigeria. Money supply ratio to GDP had a positive and significant effect on economic growth. This implies that a high money supply deepen the financial sector which promote economic growth. Money supply can create economic stimulus resulting to corporate earnings and effective supply of money to the best investments, will in turn lead to increased productivity and potentially faster economic growth. This was consistent with the findings of Nzotta et al (2009). The study carried out by Nwanna and Chinwudu (2016) reveals that both bank based and stock market financial deepening proxies has significant and positive effect on economic growth and that the banking sector and stock market in Nigeria has an important role in the process of economic growth therefore consistent with this study.

From the result, credit to private sector ratio to GDP had a positive significant effect on economic growth. This implies that increase in private sector credits would, in turn, increase the level of economic activities in the country, hence leading to increased earnings and economic growth by extension.

From the data obtained, the Ratio of Market Capitalization to GDP was positive throughout the period under investigation. However, some increase and decrease were observed owing to some factors which may include fall in Oil prices, Crash of the capital market among others. The result showed that, with there exist significant positive relationship between market capitalization and economic growth. This goes further to explain that periods of increases in market capitalization implies period of economic growth. This support the findings of Nzotta and Okereke (2009). However, this disagrees with findings made by Ohwofasa and aiyedogbon (2013), who opined that some periods of high economic activities may not translate to economic growth if factors such as inflation set in.

\section{Conclusions}

The finance-growth nexus has captured the interest of development practitioners, finance experts and researchers as well as policy makers in recent times given the turbulent experiences of the financial world and its accompanying consequences. This study assess the effect of financial deepening on (stock based, bank based) and economic growth in Nigeria from 1990 to 2016 using ordinary least square approach. The specific objectives were to estimate the impact of financial deepening measures on economic growth in Nigeria. In the process of doing this, the hypotheses that financial deepening promotes economic growth in Nigeria were validated. This study, in line with the theoretical literature, revealed a positive influence of financial deepening as measured by money supply ratio to GDP, private sector credit ratio to GDP, market capitalization ratio to GDP and financial savings ratio to GDP on economic growth of Nigeria. In the light of the above and the 
debate over the finance-growth nexus, the findings of this study should not be viewed as conclusive empirical evidence, but rather an additional motivation for further research in the area with regards to the use of indicators of financial deepening.

\section{Recommendations}

Evidence suggests stock market liquidity encourages economic growth, therefore this study recommends that policy makers should consider reducing impediments to liquidity in the stock market, easing restrictions on international capital and entry into the market to ensure that more companies are listed.

Secondly, there is an urgent need to sustain a higher level of macro-economic stability in Nigeria, reduce the high incidence of non performing credits to ensure that private sector credits are channeled to the real sector of the economy, enhance the level of corporate governance in the financial system and also strengthen risk management in the financial system.

Thirdly, high lending rates coupled with depreciating naira exchange rate have negative repercussions on the economy by discouraging long-term investment especially in new projects and those risky but productive and desirable ventures, and fuelling inflation as a result of low capacity utilization by firms. As such the monetary authority (CBN) should implement policies that increase the flow of investible funds and improves the capacity of banks to extend credit to the economy. This will make broad money supply and private sector, both as ratio of GDP to significantly impact on economic growth in Nigeria.

\section{References}

Adu, Marbuah and Mensah (2013). Financial development and Economic Growth in Ghana: Does the measure of financial development matter. The Journal of Development Finance, 3: 192-203

Agu, C. C. and Chukwu, J .O. (2008). Toda and Yamamoto Causality Tests between "Bank Based” Financial Deepening and Economic Growth in Nigeria. European Journal of Social Sciences, 7(2).

Arestis, A., Demetriades, P. \& Luintel, K. (2001). Financial Development and Economic Growth: The Role of Stock Markets. Journal of Money, Credit and Banking, 33(1): $16-41$.

CBN (1993, Central Bank of Nigerian Economic and Financial Review Department for International Development -DFID (2004)

Dernirguc-Kunt \& Levine (2008). Manufacturing growth and financial development: Evidence from OECD countries. Review of Economics and Statistics, 80(4): 638-646.

Fisher, S. (2001). The Importance of Financial Markets in Economic Growth: Memo, The Brazilian Mercantile and Futures Exchange, Citigroup, Campos do Jordao, Brazil

Ghani, (2002). Openness and Economic Growth in Pakistan. The Pakistan Development Review. 42:4 Part 11(Winter 2002) pp: 795-807

Jalilian H.and Kirkpatrick C. (2005). Does Financial Development Contribute to Poverty Reduction. The Journal of Develoment Studies, 41(4).

Kanu, S. I. and Ozurumba, B. A. (2013). Migrant’s Remittanges and Economic Growth In sub Saharan Africa: Evidence from Nigeria, Ghana and South Africa. Interdisciplinary Journal of Contemporary Research in Business, 4(10): 534-550.

Ndebbio. T. (2000). Financial Development and Economic Growth in South Africa. Department of Economics, University of Fort Hare, South Africa.

Ndebbio, J.E.U. (2004). Financial Deepening, Economic Growth and Development: Evidence $\quad$ from Selected sub- Saharan African Countries. African Economic Research Consortium (AERC) Research Paper 142, Nairobi, August

Nnanna, O. J. and Dogo, M. (1998). Structural Reform, Monetary Policy and Financial Deepening: The Nigerian Experience. Economic and Financial Review, 36(2): 1-29.

Nzotta, S.M. and Okereke, E.J. (2009). Financial Deepening and Economic Development in Nigeria: An Empirical Investigation. African Journal of Accounting, Economics, Finance and Banking Research, 5(5): 52-66 Nzotta, 2004)

Nwanna, I. O and Chinwudu, C. F. (2016). The effect of financial deepening on economic growth in Nigeria (1985-2014). Journal of Economics and Finance (IOSR-JEF), 7(4): 11-28

Odhiambho, N.M. (2004), "Financial Development and Economic Growth in South Africa. Department of Economics, University of Fort Hare, South Africa. 
Okoli, M. N. ( 2010). Evaluating the Nexus Between Financial Deepening and Stock $\quad$ Market in Nigeria. European Scientific Journal, 8(15).

Ohwofasa, B. o. and aiyedogbon, j. o. (2013). Financial deepening and economic growth in Nigeria, 19862011: an empirical investigation. Journal of Economics and Development Studies, 1(1): 24-42.

Olofin, S. and Afangideh, U. J. (2010). Financial structure and economic growth in Nigeria. Nigerian Journal of Securities and Finance, 13(1): 47-68

Patrick, H. T., (1966). Financial Development and Economic Growth in Underdeveloped Countries, Economic Development and Cultural Change, 14: 174-189.

Sahoo, S. (2013) Financial Structures and Economic Development in India: An Empirical Evaluation, RBI Working Paper No.02, Department of Economic and Policy Research, Reserve Bank of India, Mumbai

Shaw, E.S. (1973). Financial Deepening in Economic Development, Oxford

Shittu, A. I. (2012). Financial Intermediation and Economic Growth in Nigeria", British Journal of Arts and Social Sciences, 4(2).

Sulaiman, L.A., Oke, M.O. and Azeez, B.A. (2012). Effect of Financial Liberalization on Economic Growth of Developing Countries: The Nigerian Experience. International Journal of Economics and Management Sciences, 1(12): 16-28

World Bank (1989) World Development Report.

World Bank. (2010). World development indicators on online (WDI) database, Washington, DC: World Bank.

\section{Appendix}

\begin{tabular}{|c|c|c|c|c|c|}
\hline \multirow{2}{*}{ Year } & \multirow{2}{*}{$\begin{array}{c}\text { Money } \\
\text { Supply }^{2} \\
\left(\mathrm{M}_{2}\right) \\
\left(\mathrm{N}^{\prime} \text { Billion) }\right. \\
\end{array}$} & \multirow{2}{*}{$\begin{array}{c}\text { Credit to } \\
\text { Private } \\
\text { Sector }^{2}(\mathrm{CPS}) \\
\left(\mathrm{N}^{\prime} \text { Billion }\right) \\
\end{array}$} & \multirow{2}{*}{$\begin{array}{c}\text { GDP at Current } \\
\text { Basic Prices } \\
\left(\mathbf{N}^{\prime} \text { Billion }\right)\end{array}$} & \multicolumn{2}{|c|}{ Financial Deepening } \\
\hline & & & & $\begin{array}{c}\left(\mathrm{M}_{2} / \mathrm{GDP}\right) \\
(\%)\end{array}$ & $\begin{array}{c}\text { (CPS/GDP) } \\
(\%)\end{array}$ \\
\hline 1981 & 14.47 & 8.57 & 144.83 & 10.0 & 5.9 \\
\hline 1982 & 15.79 & 10.67 & 154.98 & 10.2 & 6.9 \\
\hline 1983 & 17.69 & 11.67 & 163.00 & 10.9 & 7.2 \\
\hline 1984 & 20.11 & 12.46 & 170.38 & 11.8 & 7.3 \\
\hline 1985 & 22.30 & 13.07 & 192.27 & 11.6 & 6.8 \\
\hline 1986 & 23.81 & 15.25 & 202.44 & 11.8 & 7.5 \\
\hline 1987 & 27.57 & 21.08 & 249.44 & 11.1 & 8.5 \\
\hline 1988 & 38.36 & 27.33 & 320.33 & 12.0 & 8.5 \\
\hline 1989 & 45.90 & 30.40 & 419.20 & 11.0 & 7.3 \\
\hline 1990 & 52.86 & 33.55 & 499.68 & 10.6 & 6.7 \\
\hline 1991 & 75.40 & 41.35 & 596.04 & 12.7 & 6.9 \\
\hline 1992 & 111.11 & 58.12 & 909.80 & 12.2 & 6.4 \\
\hline 1993 & 165.34 & 127.12 & $1,259.07$ & 13.1 & 10.1 \\
\hline 1994 & 230.29 & 143.42 & $1,762.81$ & 13.1 & 8.1 \\
\hline 1995 & 289.09 & 180.00 & $2,895.20$ & 10.0 & 6.2 \\
\hline 1996 & 345.85 & 238.60 & $3,779.13$ & 9.2 & 6.3 \\
\hline 1997 & 413.28 & 316.21 & $4,111.64$ & 10.1 & 7.7 \\
\hline 1998 & 488.15 & 351.96 & $4,588.99$ & 10.6 & 7.7 \\
\hline 1999 & 628.95 & 431.17 & $5,307.36$ & 11.9 & 8.1 \\
\hline 2000 & 878.46 & 530.37 & $6,897.48$ & 12.7 & 7.7 \\
\hline 2001 & $1,269.32$ & 764.96 & $8,134.14$ & 15.6 & 9.4 \\
\hline 2002 & $1,505.96$ & 930.49 & $11,332.25$ & 13.3 & 8.2 \\
\hline 2003 & $1,952.92$ & $1,096.54$ & $13,301.56$ & 14.7 & 8.2 \\
\hline 2004 & $2,131.82$ & $1,421.66$ & $17,321.30$ & 12.3 & 8.2 \\
\hline 2005 & $2,637.91$ & $1,838.39$ & $22,269.98$ & 11.8 & 8.3 \\
\hline 2006 & $3,797.91$ & $2,290.62$ & $28,662.47$ & 13.3 & 8.0 \\
\hline
\end{tabular}




\begin{tabular}{|l|c|c|c|c|c|}
\hline $\mathbf{2 0 0 7}$ & $5,127.40$ & $3,680.09$ & $32,995.38$ & 15.5 & 11.2 \\
\hline $\mathbf{2 0 0 8}$ & $8,008.20$ & $6,941.38$ & $39,157.88$ & 20.5 & 17.7 \\
\hline $\mathbf{2 0 0 9}$ & $9,411.11$ & $9,147.42$ & $44,285.56$ & 21.3 & 20.7 \\
\hline $\mathbf{2 0 1 0}$ & $11,034.94$ & $10,157.02$ & $54,612.26$ & 20.2 & 18.6 \\
\hline $\mathbf{2 0 1 1}$ & $12,172.49$ & $10,660.07$ & $62,980.40$ & 19.3 & 16.9 \\
\hline $\mathbf{2 0 1 2}$ & $13,895.39$ & $14,649.28$ & $71,713.94$ & 19.4 & 20.4 \\
\hline $\mathbf{2 0 1 3}$ & $15,160.29$ & $15,751.84$ & $80,092.56$ & 18.9 & 19.7 \\
\hline $\mathbf{2 0 1 4}$ & $17,679.29$ & $17,129.68$ & $89,043.62$ & 19.9 & 19.2 \\
\hline $\mathbf{2 0 1 5}$ & $18,901.30$ & $18,675.47$ & $94,144.96$ & 20.1 & 19.8 \\
\hline $\mathbf{2 0 1 6}^{\mathbf{3}}$ & $21,607.68$ & $21,082.72$ & $101,489.49$ & 21.3 & 20.8 \\
\hline
\end{tabular}

Sources: Central Bank of Nigeria and National Bureau of Statistics 